Article

\title{
Inverted Organic Solar Cells with Low-Temperature Al-Doped-ZnO Electron Transport Layer Processed from Aqueous Solution
}

\author{
Qianni Zhang ${ }^{1,2}$, Ruizhi Peng ${ }^{1,2}$, Chunfu Zhang ${ }^{1,2, *}{ }^{\mathbb{D}}$, Dazheng Chen ${ }^{1, *}$, Zhenhua Lin ${ }^{1}$, \\ Jingjing Chang ${ }^{1,2}$, Jincheng Zhang ${ }^{1,2}$ and Yue Hao ${ }^{1}$ \\ 1 Wide Bandgap Semiconductor Technology Disciplines State Key Laboratory, School of Microelectronics, \\ Xidian University, Xi'an 710071, China; qiannizhang93@outlook.com (Q.Z.); 18257560789@163.com (R.P.); \\ zhlin@xidian.edu.cn (Z.L.); jjingchang@xidian.edu.cn (J.C.); jchzhang@xidian.edu.cn (J.Z.); \\ yhao@xidian.edu.cn (Y.H.) \\ 2 Shaanxi Joint Key Laboratory of Graphene, Xidian University, Xi'an 710071, China \\ * Correspondence: cfzhang@xidian.edu.cn (C.Z.); dzchen@xidian.edu.cn (D.C.)
}

Received: 20 December 2017; Accepted: 26 January 2018; Published: 28 January 2018

\begin{abstract}
The aqueous-based $\mathrm{Zn}$-ammine complex solutions represent one of the most promising routes to obtain the $\mathrm{ZnO}$ electron transport layer (ETL) at a low temperature in inverted organic solar cells (OSCs). However, to dope the $\mathrm{ZnO}$ film processed from the $\mathrm{Zn}$-ammine complex solutions is difficult since the introduction of metal ions into the $\mathrm{Zn}$-ammine complex is a nontrivial process as ammonium hydroxide tends to precipitate metal salts due to acid-base neutralization reactions. In this paper, we investigate the inverted OSCs with Al-doped-ZnO ETL made by immersion of metallic $\mathrm{Al}$ into the $\mathrm{Zn}$-ammine precursor solution. The effects of $\mathrm{ZnO}$ layer with different immersion time of $\mathrm{Al}$ on film properties and solar cell performance have been studied. The results show that, with the Al-doped-ZnO ETL, an improvement of the device performance could be obtained compared with the device with the un-doped $\mathrm{ZnO}$ ETL. The improved device performance is attributed to the enhancement of charge carrier mobility leading to a decreased charge carrier recombination and improved charge collection efficiency. The fabricated thin film transistors with the same $\mathrm{ZnO}$ or AZO films confirm the improved electrical characteristics of the $\mathrm{Al}$ doped $\mathrm{ZnO}$ film.
\end{abstract}

Keywords: organic solar cell; inverted structure; electron transport layer; Al-doped-ZnO

\section{Introduction}

Organic solar cells (OSCs) based on composites of conjugated polymers (electron donor) and fullerene derivatives (electron acceptor) have attracted more and more attention due to their potential of low cost, light-weight physical features and commercial large area production [1-7]. With persistent efforts, the power conversion efficiency (PCE) of OSCs has been greatly improved to be above $10 \%$ in the past decade [2,8-19]. OSCs are mainly fabricated with two structures: the conventional structure and the inverted structure. In a typical conventional structure, the indium tin oxide (ITO) and the low-work-function metal (e.g., $\mathrm{Al}, \mathrm{Ca}$ ) are usually used as the transparent anode and opaque cathode, and an active layer (donor-accepter phase-separated blend) is sandwiched between the anode and cathode. However, the long-term stability is a problem because of the degradation of a low-work-function cathode by oxygen and water vapor and the corrosion of ITO by acidic and hygroscopic poly(3,4-ethylenedioxithiophene):poly(styrene sulfonate) (PEDOT:PSS), which is used as the hole transport layer [20-23]. To solve this problem, inverted OSCs have been developed with an improvement in stability and the capability for the roll-to-roll fabrication process. Compared with the 
conventional structure, inverted OSCs utilize ITO as the cathode and air-stable high-work-function metals like Ag as the anode [24-27].

In inverted OSCs, an n-type mental oxide as the electron transport layer (ETL) is introduced between the ITO cathode and the active layer instead of PEDOT:PSS, which improves the device stability. N-type metal oxides such as aluminum oxide $\left(\mathrm{Al}_{2} \mathrm{O}_{3}\right)$, titanium oxide $\left(\mathrm{TiO}_{\mathrm{x}}\right)$, and zinc oxide $(\mathrm{ZnO})$ have been extensively investigated [28-33]. In particular, $\mathrm{ZnO}$ has been viewed as a promising candidate as a result of several advantages such as low-cost, high transparency in visible region and stable oxidation. To obtain a high performance inverted OSC, a high conductivity ETL is required. However, the intrinsic conductivity of the $\mathrm{ZnO}$ film processed at a low temperature is still low. Therefore, developing a high performance $\mathrm{ZnO}$ thin film is a key issue. As reported previously [34-38], the doped $\mathrm{ZnO}$ film is found with better properties such as higher charge carrier mobility. In solar cells, the $\mathrm{LiF}$ doped and $\mathrm{Li}$ doped $\mathrm{ZnO}$ have been reported, and both of them were shown to enhance the charge collection efficiency and reduce the charge carrier recombination, resulting in a higher photovoltaic performance [34,35]. In the meantime, the aluminum doped and other metals' (e.g., Ba, $\mathrm{Mg}$ and $\mathrm{Sr}$ ) doped $\mathrm{ZnO}$ films have been introduced in organic light-emitting diodes, leading to higher charge carrier mobility [36-38].

The aqueous-based $\mathrm{Zn}$-ammine complex solutions represent one of the most promising routes to obtain the $\mathrm{ZnO}$ film at a low temperature due to the extremely low decomposition temperature [39-42]. This makes it possible to deposition the $\mathrm{ZnO}$ thin-film onto flexible substrates [43,44]. However, very different from the sol-gel method processed $\mathrm{ZnO}$ (where to dope the $\mathrm{ZnO}$ is relatively easy), to dope the $\mathrm{ZnO}$ film processed from the $\mathrm{Zn}$-ammine complex solutions is difficult since the introduction of metal ions into the $\mathrm{Zn}$-ammine complex is a nontrivial process as ammonium hydroxide tends to precipitate metal salts due to acid-base neutralization reaction. Recently, it has been shown that the immersion of metallic $\mathrm{Al}$ into the $\mathrm{Zn}$-ammine precursor solution for different amounts of time is an easy and efficient way to dope the $\mathrm{ZnO}$ film, which has been used in thin film transistors (TFTs) [45]. However, the $\mathrm{Al}$ doped $\mathrm{ZnO}(\mathrm{AZO})$ processed by this method has never been used in inverted OSCs.

In this paper, we investigate the inverted OSCs based on the poly(3-hexylthiophene): phenylC61-butyric acid methyl ester (P3HT:PC 61 BM) blend system and the poly(\{4,8-bis[(2-ethylhexyl)oxy] benzo[1,2-b:4,5-b'] dithiophene-2,6-diyl\}\{3-fluoro-2-[(2-ethylhexy)carbonyl]thieno[3,4-b]thiophenediyl\}): [6,6]-phenyl-C71-butyric acid methyl ester (PTB-7:PC ${ }_{71} \mathrm{BM}$ ) blend system with the immersion of metallic $\mathrm{Al}$ into the $\mathrm{Zn}$-ammine precursor solution processed $\mathrm{AZO}$ as the ETL. The effects of $\mathrm{ZnO}$ layer with different immersion times of $\mathrm{Al}$ on film properties and solar cell device performance have been studied. The results show that, when $\mathrm{Al}$ has an appropriate immersion time in the $\mathrm{ZnO}$ solution, an improvement of the device performance could be obtained compared with the device with the un-doped $\mathrm{ZnO}$ ETL because of the enhancement of charge carrier mobility leading to a decreased charge carrier recombination and improved charge collection efficiency. We also fabricate and investigate TFTs with the $\mathrm{ZnO}$ film and the results confirm the improved electrical characteristics of the $\mathrm{Al}$ doped $\mathrm{ZnO}$ film.

\section{Materials and Methods}

\subsection{Materials}

All the materials, zinc oxide (99.9\%, Sigma-Aldrich, Saint Louis, MI, USA), ammonia solution ( $\geq 28 \%, \mathrm{NH}_{3}$ in $\mathrm{H}_{2} \mathrm{O}$, Aladdin, Hamden, $\mathrm{CT}, \mathrm{USA}$ ), poly(3-hexylthiophene) (P3HT, BASF), phenyl- $\mathrm{C}_{61}$-butyric acid methyl ester $\left(\mathrm{PC}_{61} \mathrm{BM}, 98 \%\right.$, Nano-C, Westwood, MA, USA), poly(\{4,8-bis[(2ethylhexyl)oxy]benzo[1,2-b:4,5-b']dithiophene-2,6-diyl\}\{3-fluoro-2-[(2-ethylhexy)carbonyl]thieno[3,4-b] thiophenediyl\}) (PTB-7, 1-material), [6,6]-phenyl-C71-butyric acid methyl ester ( $\mathrm{PC}_{71} \mathrm{BM}, 99 \%$, Nano-C), 1,8-diiodooctane (DIO, 98\%, Sigma-Aldrich), 1,2-dichlorobenzene (99\%, Sigma-Aldrich), chlorobenzene (99.8\%, Sigma-Aldrich), molybdenum oxide $\left(\mathrm{MoO}_{3}, 99.98 \%\right.$, Sigma-Aldrich) are used as received without further purification. 
For the low-temperature aqueous solution processing, $\mathrm{ZnO}$ solution was obtained by $\mathrm{ZnO}$ powder directly dissolved in ammonia solution $(8 \mathrm{mg} / \mathrm{mL})$. For Al-doped-ZnO (AZO), Al was added into well prepared $\mathrm{ZnO}$ solution with different immersion times.

\subsection{Film Formation and Inverted Solar Cells Fabrication}

Inverted OSCs were fabricated on pre-patterned ITO glass substrates (around $2 \times 2.5 \mathrm{~cm}^{2}$ in size, $10 \Omega$ per square, surface roughness of $2-3 \mathrm{~nm}$ ). The patterned ITO glass substrates were sequentially cleaned with detergent, de-ionized water, acetone, alcohol and isopropyl alcohol in an ultrasonic bath at $50{ }^{\circ} \mathrm{C}$ for $20 \mathrm{~min}$, respectively. Then, the cleaned ITO substrates were dried with nitrogen and treated in a UV ozone oven for $15 \mathrm{~min}$. After that, on the top of the ITO substrates, the ZnO solution was spin-coated at $3000 \mathrm{rpm}$ for $45 \mathrm{~s}$, and thermally annealed in the baking oven at $150{ }^{\circ} \mathrm{C}$ for $30 \mathrm{~min}$. Subsequently, the substrates were transferred into a nitrogen-filled glovebox. The active layer solution used P3HT and $\mathrm{PC}_{61} \mathrm{BM}$ blend with a weight ratio of 1:1 in 1,2-dichlorobenzene(1,2-DCB) $(20 \mathrm{mg} / \mathrm{mL})$. The blend solution was spin-coated on the $\mathrm{ZnO}$ layer at $800 \mathrm{rpm}$ for $120 \mathrm{~s}$, and the active layer was annealed at $150{ }^{\circ} \mathrm{C}$ for $15 \mathrm{~min}$. Finally, the devices were finished by thermal evaporation of $8 \mathrm{~nm} \mathrm{MoO}_{3}$ layer and $80 \mathrm{~nm}$ Ag electrode. The device area is $7 \mathrm{~mm}^{2}$.

For OSCs based on the PTB-7:PC 71 BM blend system, the same device fabrication procedures were used except the spin coating of the PTB-7 and $\mathrm{PC}_{71} \mathrm{BM}$ blend (weight ratio of 2:3 in chlorobenzene with $3 \mathrm{vol} \% \mathrm{DIO}$ ) at $1000 \mathrm{rpm}$ for $60 \mathrm{~s}$, and the following dried in the shade at least for $5 \mathrm{~h}$.

The TFTs were fabricated with the same $\mathrm{ZnO}$ solution used in solar cells. Before the film fabrication, the cleaned $\mathrm{Si} / \mathrm{SiO}_{2}(100 \mathrm{~nm})$ wafer should be treated with $\mathrm{O}_{2}$ plasma for 10 min to remove the surface residues and facilitate the thin film formation. The $\mathrm{ZnO}$ solution was spin-coated on the wafer at $3000 \mathrm{rpm}$ for $30 \mathrm{~s}$, annealed at $300{ }^{\circ} \mathrm{C}$ for $5 \mathrm{~min}$, and then spin-coated a second time with the same condition. Finally, a $100 \mathrm{~nm}$ Al layer was deposited on the top of $\mathrm{ZnO}$ to form the source and drain contacts.

\subsection{Device Characterization}

The photovoltaic performances of OSCs were measured by using a Keithley 2400 source meter (Tektronix, Inc., OR, USA) under a simulated AM 1.5G sunlight from XES-70S1 solar simulator (XES-301, SEN-EI Electric. Co. Ltd, Osaka, Japan) with an intensity of $100 \mathrm{~mW} / \mathrm{cm}^{2}$. The system was calibrated against a National Renewable Energy Laboratory (NREL) certified silicon reference solar cell. Incident photo-to-electron conversion efficiency (IPCE) was measured under short-circuit conditions by a solar cell quantum efficiencies system (SCS10-X150, Zolix instrument. Co. Ltd., Beijing, China) with a monochromatic light from an arc lamp.

The surface morphologies of the $\mathrm{ZnO}$ films and the active layers deposited on different $\mathrm{ZnO}$ films were characterized by an atomic force microscopy (AFM, Bruker Dimension Icon, Bruker, Karlsruhe, Germany). The UV-visible absorption spectra were recorded with an UV-visible spectrophotometer (Perkin-Elmer Lambda 950, Waltham, MA, USA). All of the above measurements were performed under ambient atmosphere at room temperature without encapsulation.

\section{Results and Discussion}

The schematic device structure and the energy level diagram of the component materials of the inverted P3HT:PC 61 BM OSCs are shown in Figure 1a,b. In this paper, we use the inverted device structure of ITO/ $\mathrm{ZnO}(\mathrm{AZO}) /$ active layer $/ \mathrm{MoO}_{3} / \mathrm{Ag}$. From Figure $1 \mathrm{~b}$, the conduction band minimum of $\mathrm{ZnO}$ is approximately $4.0 \mathrm{eV}$, which is closed to the lowest unoccupied molecular orbital (LUMO) of $\mathrm{PC}_{61} \mathrm{BM}$, leading to a facilitated electron transport to ITO cathode, since the valance band maximum of $\mathrm{ZnO}$ is anticipated at $7.4 \mathrm{eV}$, which will effectively block the hole from the highest occupied molecular orbital (HOMO) of P3HT. 


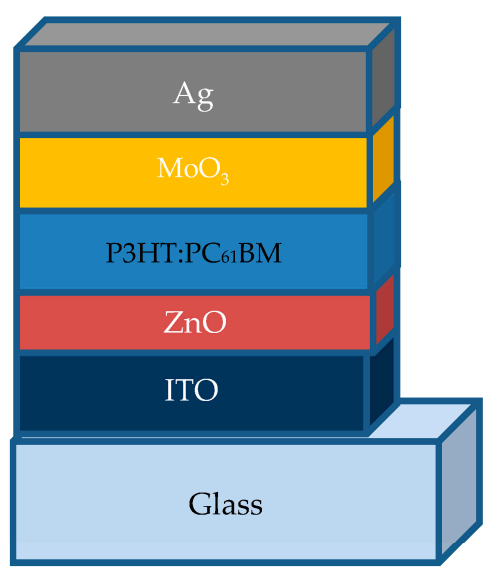

(a)

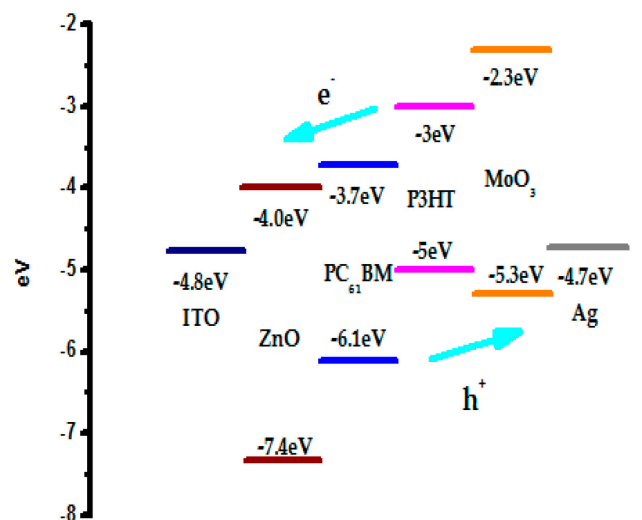

(b)

Figure 1. (a) Schematic poly(3-hexylthiophene): phenyl-C61-butyric acid methyl ester (P3HT:PC $\left.{ }_{61} \mathrm{BM}\right)$ device structure used in this paper. The thickness of each layer is not in scale with the real thickness for clarity; (b) Schematic illustration of the energy levels of the component materials of the studied devices.

Figure 2 illustrates the current density vs. voltage $(\mathrm{J}-\mathrm{V})$ characteristics of the inverted OSCs introducing the $\mathrm{ZnO}$ buffer layer un-doped and doped with different amounts of Al by controlling different immersion times. The parameters of OSCs are extracted according to the Shockley equation:

$$
J=J_{0}\left(\exp \left(\frac{q\left(V-R_{s} J\right)}{n K_{B} T}\right)-1\right)+\frac{V-R_{s} J}{R_{s h}}-J_{p},
$$

where $J_{0}$ is the saturation current, $J_{p}$ the photocurrent, $R_{s}$ the series resistance, $R_{s h}$ the shunt resistance, $n$ the ideality factor, $q$ the electron charge, $k_{B}$ the Boltzmann constant, and $T$ the temperature. By using Equation (1) with our proposed explicit analytic expression method [46], the experimental data were extracted and these parameters could rebuild the I-V curves of the OSCs as shown in Figure 2, which confirmed the validity of the extracted parameters. The photovoltaic performance parameters of the best devices are summarized in Table 1 . The device based on the pure $\mathrm{ZnO}$ buffer layer shows a short-circuit current density (JSC) of $6.95 \mathrm{~mA} / \mathrm{cm}^{2}$ and a fill factor (FF) of $63.38 \%$. With $\mathrm{Al}$ immersion time form $4 \mathrm{~min}$ to $16 \mathrm{~min}$, both of them have an obvious increase. The increased FF may be due to the reduced charge recombination and increased shunt resistance $\left(R_{s h}\right)$. In particular, when the $\mathrm{Al}$ immersion time is $8 \mathrm{~min}$, the device shows the optimized performance with JSC of $7.21 \mathrm{~mA} / \mathrm{cm}^{2}$ and FF of $68.21 \%$. Therefore, PCE of the device increases from $2.79 \%$ to $3.09 \%$. However, when the immersion time is increased to $16 \mathrm{~min}$, there shows a slight decrease in $\mathrm{J}_{\mathrm{SC}}, \mathrm{FF}$ and PCE. Since the JSC value is related to the properties of the ETL. It is inferred that when the $\mathrm{Al}$ immersion time is short, the doped $\mathrm{Al}$ could improve the charge carrier mobility and thus enhance the device performance. However, when the $\mathrm{Al}$ immersion time is long, the excess $\mathrm{Al}$ will become the scattering center, which will partly decrease the charge carrier mobility. This will be confirmed by the following charge carrier mobility measurement. Figure 3 shows the statistical results of the dependence of open circuit voltage $\left(\mathrm{V}_{\mathrm{OC}}\right), \mathrm{FF}, \mathrm{J}_{\mathrm{SC}}$ and PCE on the immersion time of $\mathrm{Al}$ in the $\mathrm{ZnO}$ solution. From the statistical results, it could be seen that the device with the $\mathrm{Al}$ immersion time at 8 min shows the best performance, which confirms the validity of the above discussion. From Figure 3, it is found that $\mathrm{V}_{\mathrm{OC}}$ slightly increases after doping $\mathrm{Al}$ into the $\mathrm{ZnO}$ solution from $4 \mathrm{~min}$ to $16 \mathrm{~min}$. It corresponds to the previous report that $\mathrm{V}_{\mathrm{OC}}$ of the device increases with the increase of Al doping amount due to the Fermi energy shift of AZO film [47]. Meanwhile, $\mathrm{V}_{\mathrm{OC}}$ is related to the photon energy loss. The smaller photon energy loss occurred in the device may be caused by the reduced interface related recombination or energy loss, which will result in a higher $V_{O C}$. 


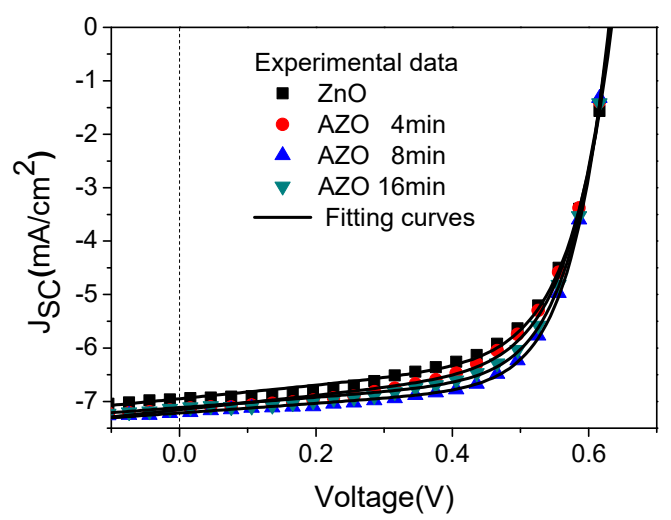

Figure 2. J-V characteristics of the $\mathrm{P} 3 \mathrm{HT}: \mathrm{PC}_{61} \mathrm{BM}$ devices introducing the $\mathrm{ZnO}$ film without and with the different immersion times of $\mathrm{Al}$ doping.

Table 1. Photovoltaic parameters of best inverted structure $\mathrm{P} 3 \mathrm{HT}: \mathrm{PC}_{61} \mathrm{BM}$ solar cells with $\mathrm{ZnO}$ or Al-doped-ZnO (AZO) as the electron transport layer ETL.

\begin{tabular}{ccccc}
\hline Device & V $_{\text {OC }}(\mathbf{V})$ & $\mathrm{JSC}_{\text {SC }}\left(\mathbf{m A} / \mathbf{c m}^{\mathbf{2}}\right)$ & FF (\%) & PCE (\%) \\
\hline ZnO & 0.634 & 6.95 & 63.38 & 2.79 \\
AZO 4 min & 0.628 & 7.13 & 64.21 & 2.88 \\
AZO 8 min & 0.628 & 7.21 & 68.21 & 3.09 \\
AZO 16 min & 0.628 & 7.11 & 66.94 & 2.99 \\
\hline
\end{tabular}
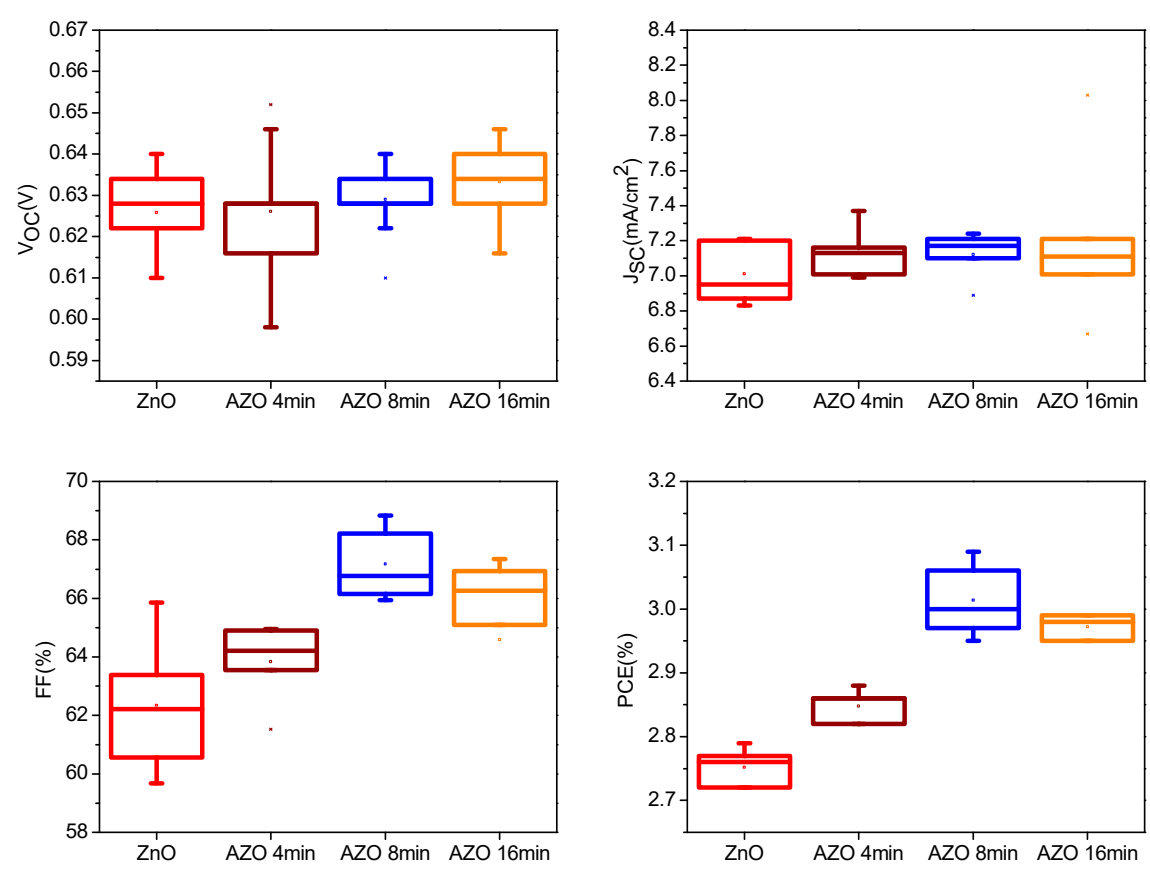

Figure 3. The statistical results of the photovoltaic parameters of the inverted organic soalr cells (OSCs) incorporating the $\mathrm{ZnO}$ layer without and with the different $\mathrm{Al}$ immersion time. Every statistical result is derived from more than 20 devices.

Incident photon-to-current conversion efficiency (IPCE) spectra of the $\mathrm{ZnO}(\mathrm{AZO}) / \mathrm{P} 3 \mathrm{HT}: \mathrm{PC}_{61} \mathrm{BM}$ devices are presented in Figure 4. Compared with the maximum IPCE 53.7\% of the device with the pure $\mathrm{ZnO}$ ETL, the devices with the $8 \mathrm{~min}$ and $16 \mathrm{~min}$ AZO buffer layers have the maximum IPCE of $61.18 \%$ and $63.07 \%$ at the wavelength around $500 \mathrm{~nm}$, respectively. The integrated IPCE value of device 
with $8 \mathrm{~min}$ AZO thin film is $7.42 \mathrm{~mA} / \mathrm{cm}^{2}$, which is close to the measured JSC. The IPCE measurement results also confirm that the device with the $8 \mathrm{~min}$ AZO buffer layer has the best performance.

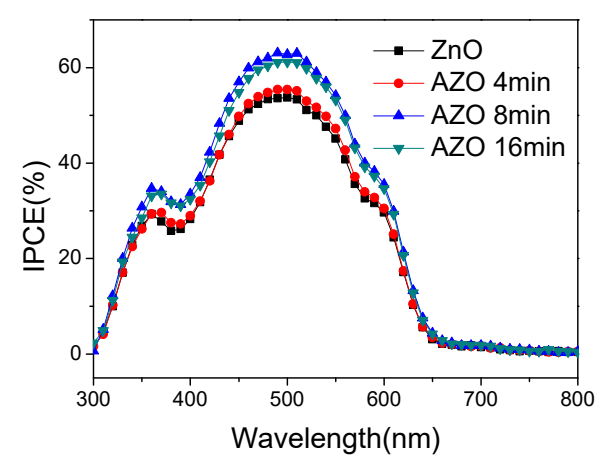

Figure 4. Incident photon-to-current conversion efficiency (IPCE) spectra of inverted P3HT:PC ${ }_{61} \mathrm{BM}$ solar cells.

The transmittance spectra of the ZnO ETL and the absorption spectra of the active layer (P3HT:PC ${ }_{61} \mathrm{BM}$ ) with difference $\mathrm{Al}$ immersion times are shown in Figure $5 \mathrm{a}, \mathrm{b}$. As can be seen, all of the $\mathrm{ZnO} / \mathrm{ITO}$ films have similar good transmittance in the visible wavelength range (from $300 \mathrm{~nm}$ to $800 \mathrm{~nm}$ ). It indicates that doping $\mathrm{Al}$ into the $\mathrm{ZnO}$ solution has a minimal effect on the transmittance of the $\mathrm{ZnO}$ thin film. As shown in Figure 5b, the absorption of the active layer with the un-doped $\mathrm{ZnO}$ layer is a bit higher at the wavelength from $400 \mathrm{~nm}$ to $600 \mathrm{~nm}$. This shows that the introduction of $\mathrm{Al}$ in the ETL could slightly reduce the absorption ability of the active layer. Although the mechanism behind this is still not known, it indicates that the improvement of the device performance with the AZO ETL is due to the improved electrical properties of the AZO layer instead of the improved light absorption.

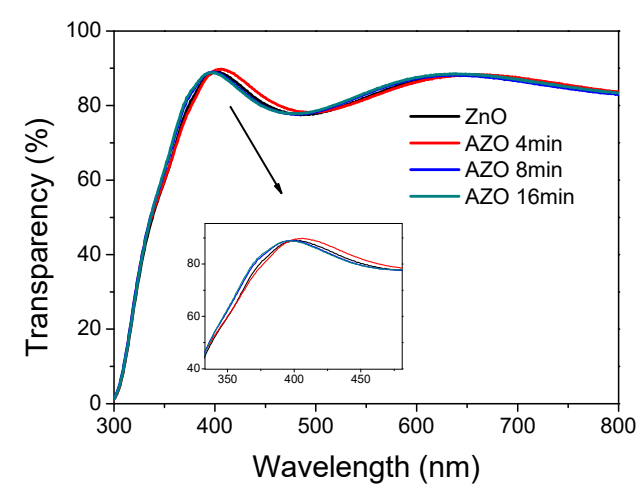

(a)

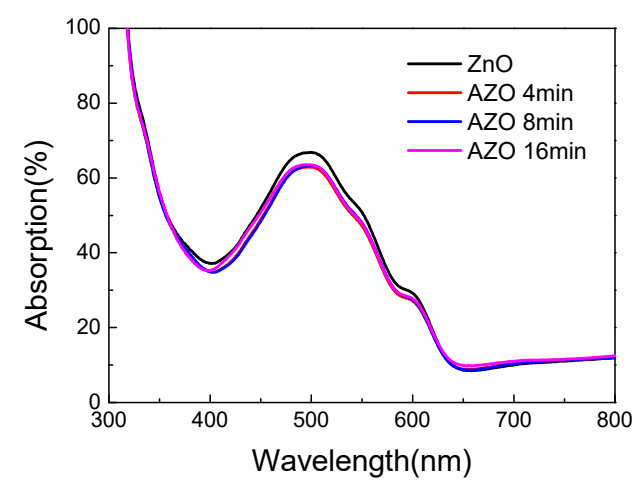

(b)

Figure 5. (a) The transmittance spectra of the $\mathrm{ZnO}$ the electron transport layer (ETL); (b) The absorption spectra of the active layer (P3HT:PC 61 BM) with difference $\mathrm{Al}$ immersion times.

In order to further investigate the $\mathrm{ZnO} / \mathrm{AZO}$ films, the surface morphologies of them and P3HT:PC ${ }_{61} \mathrm{BM}$ active layers were measured by the atomic force microscopy (AFM). The results are illustrated in Figure 6. For the increase of the immersion time of $\mathrm{Al}$ in $\mathrm{ZnO}$ solution, the topography images (Figure 6a-d) changes significantly. The surface of the AZO film is rougher than the pure $\mathrm{ZnO}$ film and the root-mean-square (rms) values of the surface roughness increases from $0.283 \mathrm{~nm}$ to $3.430 \mathrm{~nm}$ for the $\mathrm{Al}$ immersion time from $0 \mathrm{~min}$ to $16 \mathrm{~min}$. On one side, the rougher ETL increases the contact area with active layer, from which the electron collection may benefit and lead to an increased $\mathrm{JSC}_{\mathrm{SC}}$. On the other side, if the roughness is too large, when voltage on the device is added, it is easier to cause the device breakdown. Combing the measured device performance in Figures 2 and 3, the 
immersion time of $8 \mathrm{~min}$ is optimal. Compared with obvious changes on the surface of the $\mathrm{ZnO}$ film, the surface morphologies of the P3HT:PC ${ }_{61} \mathrm{BM}$ active layer with the $\mathrm{ZnO}$ or AZO ETL almost remain unchanged. The result indicates that the surface morphology of the $\mathrm{ZnO}$ buffer layer almost has a minimal effect on the topography of active layer. It is inferred that other factors such as the electrical properties could affect the device performance.

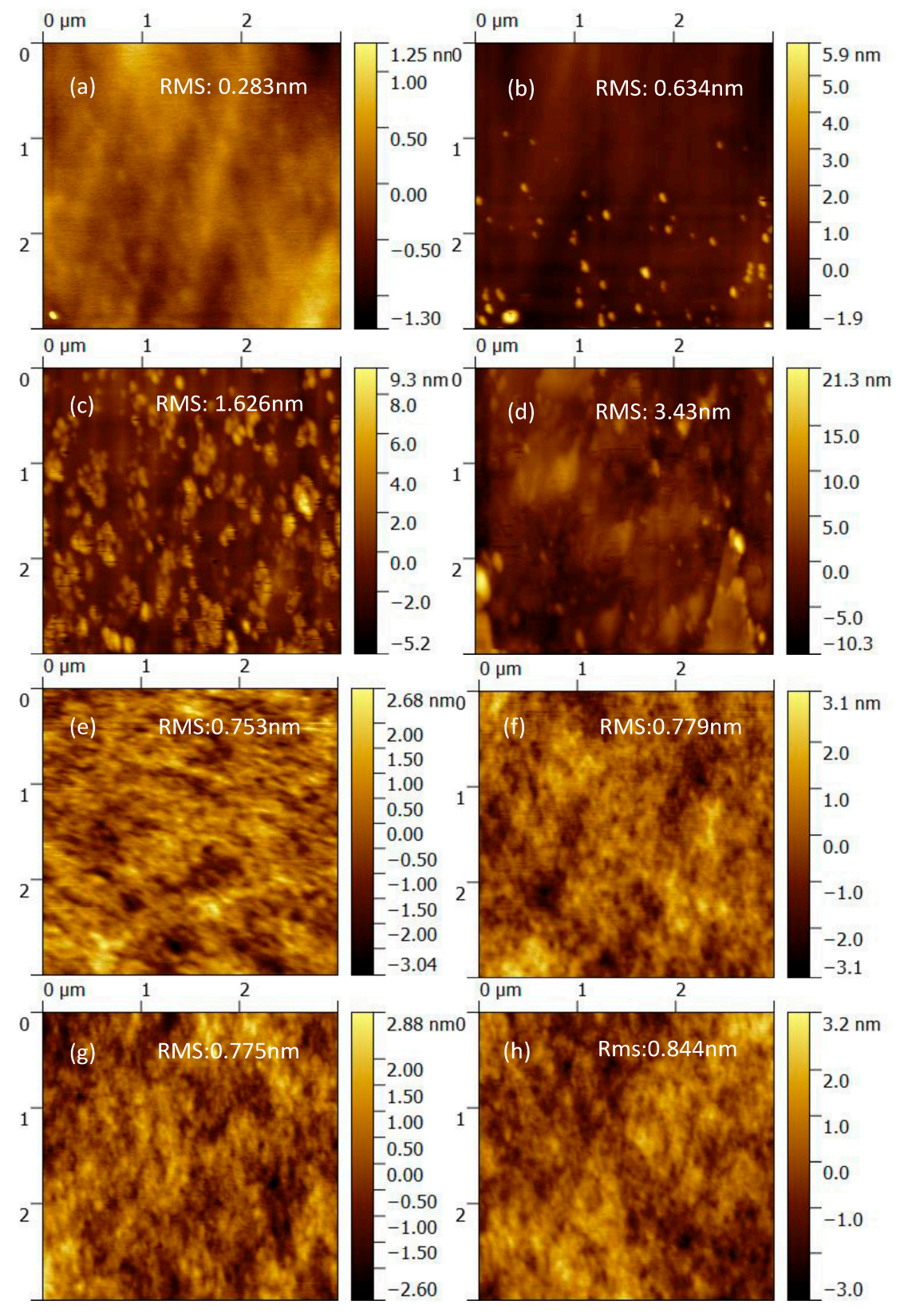

Figure 6. (a-d) Surface morphologies of $\mathrm{ZnO}$ thin film; (e-h) Surface morphologies of $\mathrm{ZnO}(\mathrm{AZO}) / \mathrm{P} 3 \mathrm{HT}: \mathrm{PC}_{61} \mathrm{BM}$, without or with $\mathrm{Al}$ immersion time of $4 \mathrm{~min}, 8 \mathrm{~min}$ and $16 \mathrm{~min}$, respectively.

To evaluate the electrical properties of the $\mathrm{ZnO} / \mathrm{AZO}$ films, the transistors are fabricated. The transfer characteristics for the ZnO TFTs with different Al immersion times are shown in Figure 7. The results show that TFTs fabricated with the un-doped $\mathrm{ZnO}$ film exhibit an electron mobility of $0.18 \mathrm{~cm}^{2} \cdot \mathrm{V}^{-1} \cdot \mathrm{s}^{-1}$, and with the increase of the $\mathrm{Al}$ immersion time, the electron mobility increases to $0.95 \mathrm{~cm}^{2} \cdot \mathrm{V}^{-1} \cdot \mathrm{s}^{-1}$ (8 min). As shown in Figure 7 , the drain current increases by doping Al into $\mathrm{ZnO}$. However, the current begins to decrease when the immersion time is further increased to 16 min. This 
is consistent with the performance change of OSCs. The results above indicate that an appropriate amount of $\mathrm{Al}$ doped into $\mathrm{ZnO}$ solution can improve the properties of the film, resulting in better performance in both TFTs and inverted OSCs.

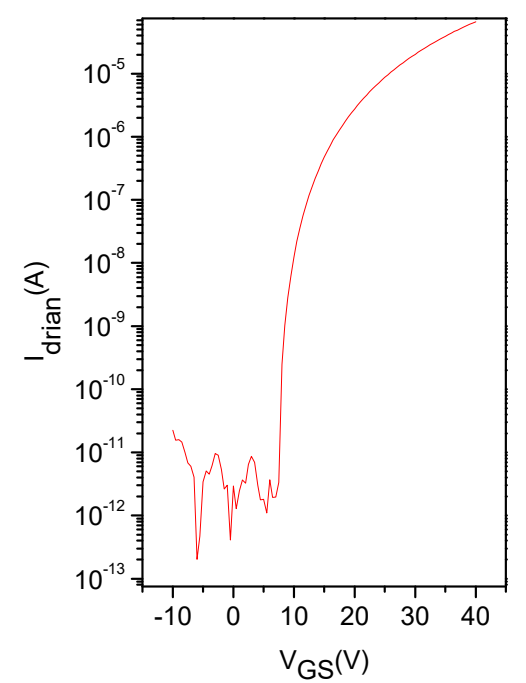

(a)

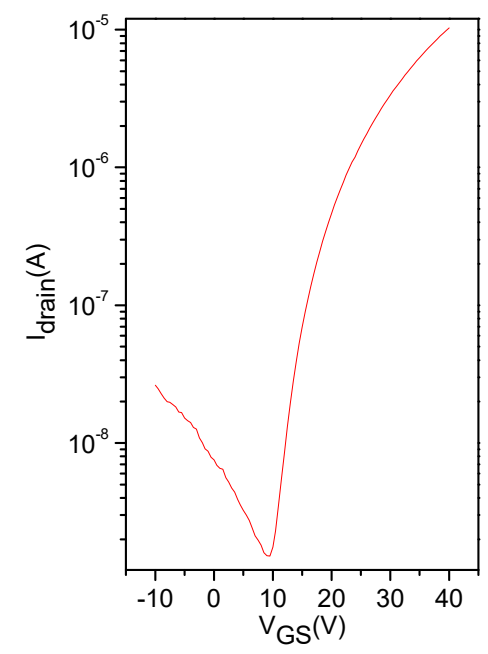

(c)

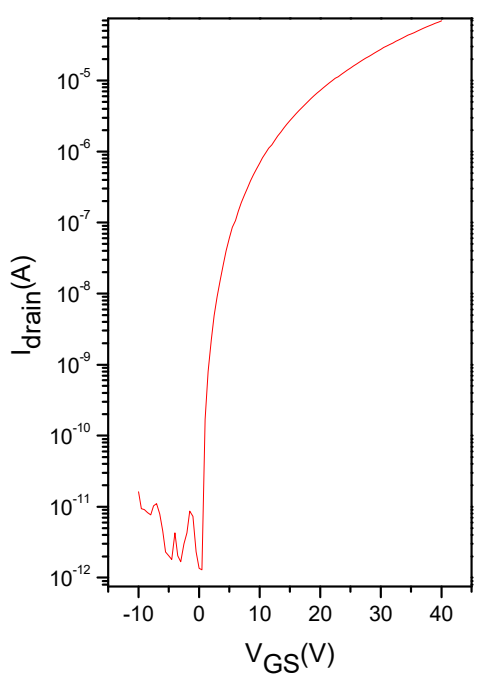

(b)

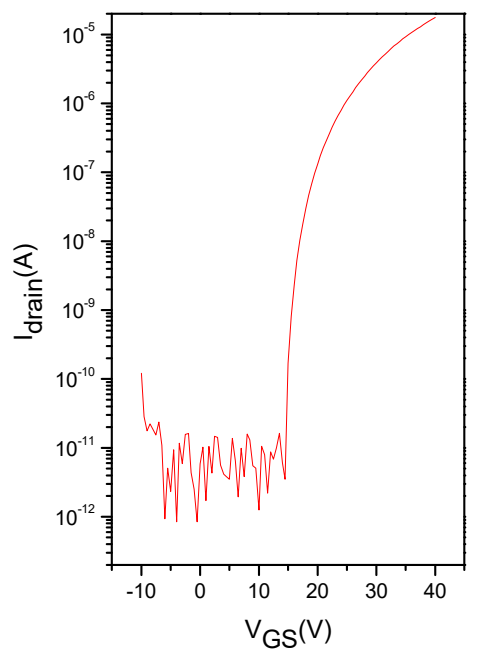

(d)

Figure 7. Transfer characteristics of $\mathrm{Al}$ doped $\mathrm{ZnO}$ thin film transistors (TFTs) with different reaction times (0 $\min (\mathbf{a}), 4 \mathrm{~min}(\mathbf{b}), 8 \mathrm{~min}(\mathbf{c})$ and $16 \mathrm{~min}(\mathbf{d}))$.

To further confirm the validity of using $\mathrm{Al}$ doped $\mathrm{ZnO}$ as ETL to improve the device performance, the PTB-7:PC ${ }_{71}$ BM OSCs were also fabricated. Figure 8 shows the corresponding schematic device structure and the energy level diagram of the component materials. The structure is similar to the P3HT:PC ${ }_{61} B M$ OSCs except for the active layer.

The photovoltaic performance parameters of the best PTB-7:PC 71 BM devices are summarized in Table 2, and the J-V curves are shown in Figure 9. From the parameters, it is shown that the PCE of the device with $\mathrm{AZO}$ as ETL is higher than that with $\mathrm{ZnO}(7.39 \%)$, especially the AZO device with immersion time of $\mathrm{Al}$ at $8 \mathrm{~min}(7.86 \%)$. Furthermore, in the PTB-7:PC ${ }_{71} \mathrm{BM}$ system, using proper $\mathrm{AZO}$ can also improve the $\mathrm{V}_{\mathrm{OC}}$ and FF. The IPCE measurement results in Figure $9 \mathrm{~b}$ also show that the device with the $\mathrm{Al}$ immersion time of 8 min achieves the highest value, which corresponds to the best device performance. The statistical results of the photovoltaic parameters in Figure 10 further confirmed the validity of above discussion. 
(a)

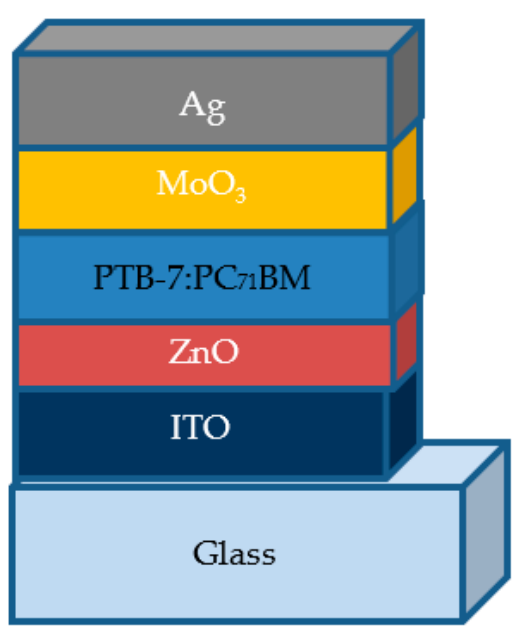

(b)

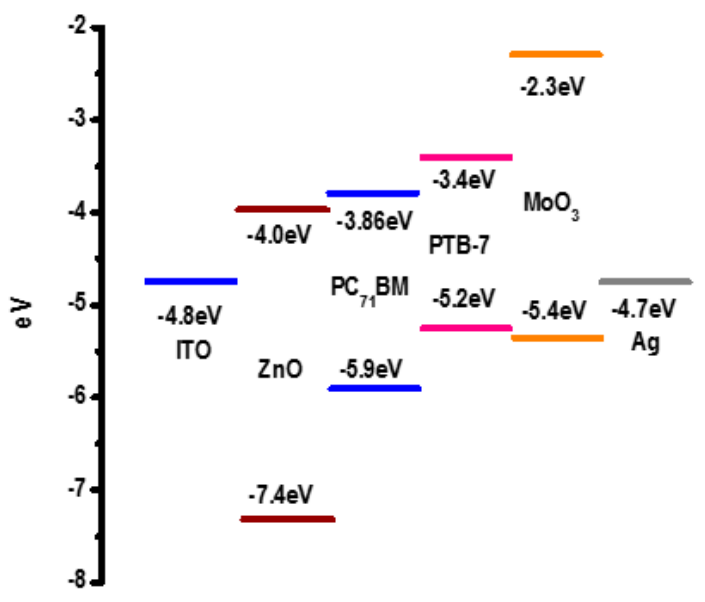

Figure 8. (a) Schematic device structure with PTB-7:PC 71 BM. The thickness of each layer is not on scale with the real thickness for clarity; (b) Schematic illustration of the energy levels of the component materials of PTB-7:PC 71 BM devices.

Table 2. Photovoltaic parameters of best inverted structure PTB-7:PC 71 BM solar cells with $\mathrm{ZnO}$ or $\mathrm{AZO}$ as the ETL.

\begin{tabular}{ccccc}
\hline Device & $\mathbf{V}_{\text {OC }}(\mathbf{V})$ & $\mathrm{J}_{\text {SC }}\left(\mathbf{m A} / \mathbf{c m}^{\mathbf{2}}\right)$ & FF (\%) & PCE (\%) \\
\hline ZnO & 0.721 & 14.52 & 70.58 & 7.39 \\
AZO 4 min & 0.731 & 14.96 & 69.57 & 7.61 \\
AZO 8 min & 0.732 & 15.13 & 70.98 & 7.86 \\
AZO 16 min & 0.723 & 15.06 & 69.88 & 7.60 \\
\hline
\end{tabular}

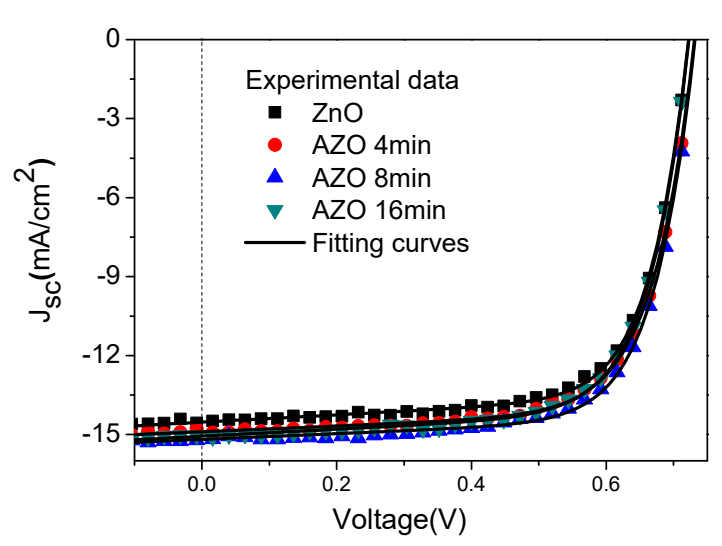

(a)

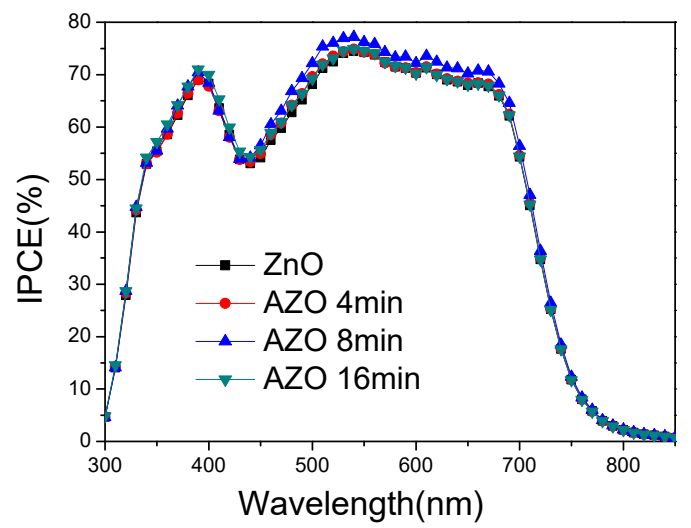

(b)

Figure 9. (a) J-V characteristics of the PTB-7:PC $\mathrm{P}_{71} \mathrm{BM}$ devices introducing the $\mathrm{ZnO}$ film without and with the different immersion times of $\mathrm{Al}$ doping; (b) IPCE spectra of the corresponding PTB-7:PC 71 BM solar cells. 

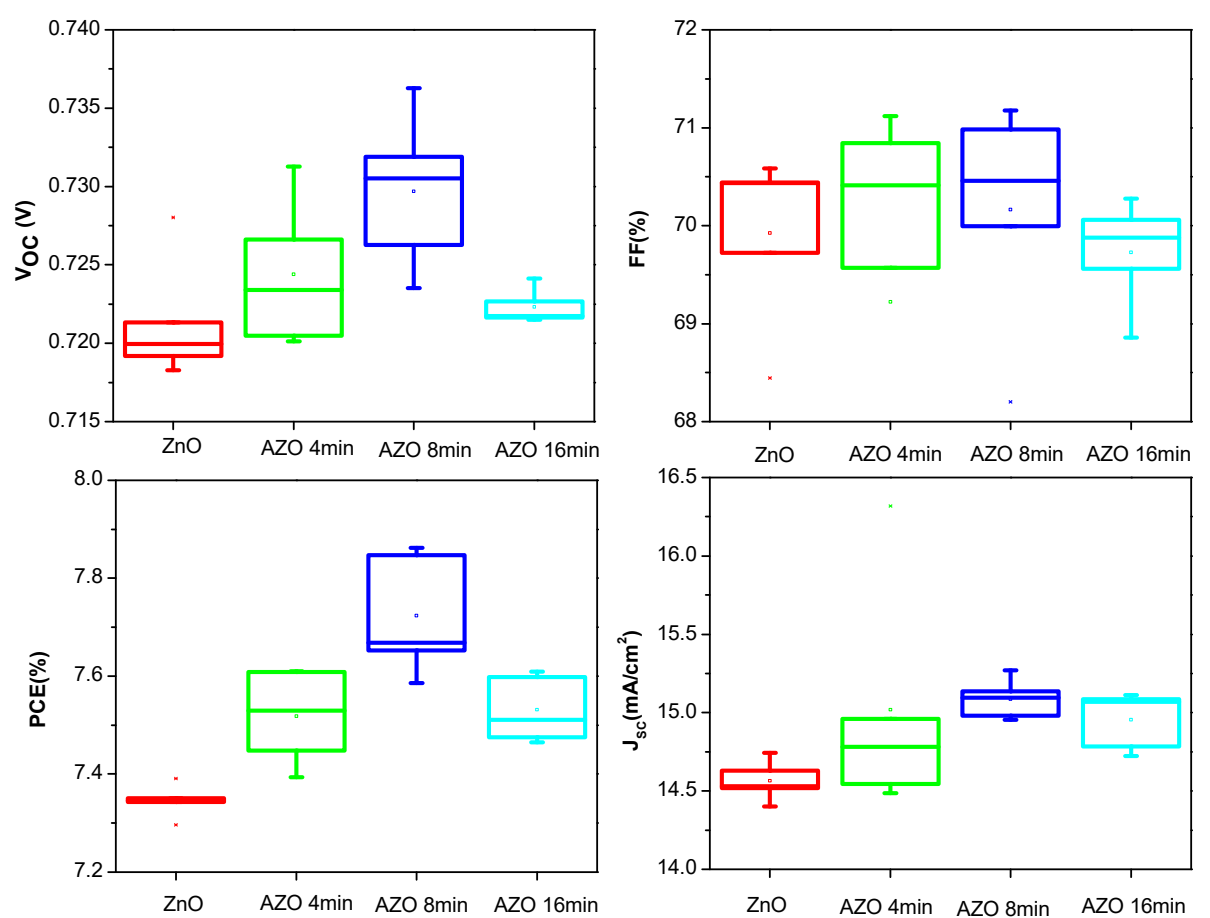

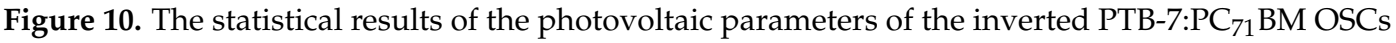
incorporating the $\mathrm{ZnO}$ layer without and with the different $\mathrm{Al}$ immersion times. Every statistical result is derived from more than 20 devices.

\section{Conclusions}

In summary, Al-doped-ZnO (AZO) thin film as the ETL in inverted OSCs has been fabricated via spin coating aqueous solution, which is a low temperature processing. Using $\mathrm{AZO}$ (immersion time $8 \mathrm{~min}$ ) as the buffer layer in P3HT:PC ${ }_{61} \mathrm{BM}$ system, PCE increases to $3.09 \%$, compared with the control device with a pure $\mathrm{ZnO}$ device (PCE 2.79\%) under the same conditions. Furthermore, in a PTB-7:PC ${ }_{71} \mathrm{BM}$ system, PCE with AZO (immersion time $8 \mathrm{~min}$ ) can be improved to be $7.86 \%$ (pure $\mathrm{ZnO}, \mathrm{PCE} 7.39 \%$ ). Our result suggests that $\mathrm{AZO}$ with this simple doping method can improve the performance of inverted OSCs.

Acknowledgments: This work was supported primarily by National Natural Science Foundation of China (61334002, 61106063, and 11435010), the Fundamental Research Funds for the Central Universities (JB181107), and Class General Financial Grant from the China Postdoctoral Science Foundation (2016M602771).

Author Contributions: Chunfu Zhang conceived the idea, guided the experiment and revised the manuscript. Qianni Zhang conducted most of the device fabrication, data collection and wrote the manuscript; Dazheng Chen, Zhenhua Lin and Jingjing Chang helped the device measurement, Jincheng Zhang gave the advices about the experiments, Yue Hao supervised the team. All authors read and approved the manuscript.

Conflicts of Interest: The authors declare no conflict of interest.

\section{References}

1. Krebs, F.C.; Nielsen, T.D.; Fyenbo, J.; Wadstrøm, M.; Pedersen, M.S. Manufacture, integration and demonstration of polymer solar cells in a lamp for the "Lighting Africa" initiative. Energy Environ. Sci. 2010, 3, 512-525. [CrossRef]

2. Liang, Y.; Yu, L. A New Class of Semiconducting Polymers for Bulk Heterojunction Solar Cells with Exceptionally High Performance. Acc. Chem. Res. 2010, 43, 1227-1236. [CrossRef] [PubMed]

3. Wang, T.; Scarratt, N.W.; Yi, H.; Dunbar, A.D.F.; Pearson, A.J.; Watters, D.C.; Glen, T.S.; Brook, A.C.; Kingsley, J.; Buckley, A.R.; et al. Fabricating High Performance, Donor-Acceptor Copolymer Solar Cells by Spray-Coating in Air. Adv. Energy Mater. 2013, 3, 505-512. [CrossRef] 
4. Li, N.; Baran, D.; Spyropoulos, G.D.; Zhang, H.; Berny, S.; Turbiez, M.; Ameri, T.; Krebs, F.C.; Brabec, C.J. Environmentally Printing Efficient Organic Tandem Solar Cells with High Fill Factors: A Guideline Towards 20\% Power Conversion Efficiency. Adv. Energy Mater. 2014, 4, 1400084. [CrossRef]

5. Lin, Z.; Chang, J.; Zhang, J.; Jiang, C.; Wu, J.; Zhu, C. A work-function tunable polyelectrolyte complex (PEI:PSS) as a cathode interfacial layer for inverted organic solar cells. J. Mater. Chem. A 2014, 2, 7788-7794. [CrossRef]

6. Lee, B.R.; Lee, S.; Park, J.H.; Jung, E.D.; Yu, J.C.; Nam, Y.S.; Heo, J.; Kim, J.; Kim, B.; Song, M.H. Amine-Based Interfacial Molecules for Inverted Polymer-Based Optoelectronic Devices. Adv. Mater. 2015, 27, 3553-3559. [CrossRef] [PubMed]

7. Chalal, D.; Garuz, R.; Benachour, D.; Bouclé, J.; Ratier, B. Influence of an electrode self-protective architecture on the stability of inverted polymer solar cells based on P3HT:PCBM with an active area of $2 \mathrm{~cm}^{2}$. Synth. Met. 2016, 212, 161-166. [CrossRef]

8. Vohra, V.; Kawashima, K.; Kakara, T.; Koganezawa, T.; Osaka, I.; Takimiya, K.; Murata, H. Efficient inverted polymer solar cells employing favourable molecular orientation. Nat. Photon. 2015, 9, 403-408. [CrossRef]

9. Kan, B.; Zhang, Q.; Li, M.; Wan, X.; Ni, W.; Long, G.; Wang, Y.; Yang, X.; Feng, H.; ChenL, Y. Solution-Processed Organic Solar Cells Based on Dialkylthiol-Substituted Benzodithiophene Unit with Efficiency near 10\%. J. Am. Chem. Soc. 2014, 136, 15529-15532. [CrossRef] [PubMed]

10. Brabec, C.J.; Gowrisanker, S.; Halls, J.J.M.; Laird, D.; Jia, S.; Williams, S.P. Polymer-Fullerene Bulk-Heterojunction Solar Cells. Adv. Mater. 2010, 22, 3839-3856. [CrossRef] [PubMed]

11. Huang, J.; Li, C.; Chueh, C.; Liu, S.; Yu, J.; Jen, A.K. 10.4\% Power Conversion Efficiency of ITO-Free Organic Photovoltaics through Enhanced Light Trapping Configuration. Adv. Energy Mater. 2015, 5, 1500406. [CrossRef]

12. Nguyen, T.L.; Choi, H.; Ko, S.-J.; Uddin, M.A.; Walker, B.; Yum, S.; Jeong, J.-E.; Yun, M.H.; Shin, T.J.; Hwang, S.; et al. Semi-crystalline photovoltaic polymers with efficiency exceeding $9 \%$ in a $~ 300 \mathrm{~nm}$ thick conventional single-cell device. Energy Environ. Sci. 2014, 7, 3040-3051. [CrossRef]

13. Ye, L.; Zhao, W.; Li, S.; Mukherjee, S.; Carpenter, J.H.; Awartani, O.; Jiao, X.; Hou, J.; Ade, H. High-Efficiency Nonfullerene Organic Solar Cells: Critical Factors that Affect Complex Multi-Length Scale Morphology and Device Performance. Adv. Energy Mater. 2017, 7, 1602000. [CrossRef]

14. Zhong, H.; Ye, L.; Chen, J.; Jo, S.B.; Chueh, C.; Carpenter, J.H.; Ade, H.; Jen, A.K.-Y. A regioregular conjugated polymer for high performance thick-film organic solar cells without processing additive. J. Mater. Chem. A 2017, 5, 10517. [CrossRef]

15. Ye, L.; Zhang, S.; Zhao, W.; Yao, H.; Hou, J. Highly Efficient 2D-Conjugated Benzodithiophene-Based Photovoltaic Polymer with Linear Alkylthio Side Chain. Chem. Mater. 2014, 26, 3603-3605. [CrossRef]

16. Ye, L.; Jiao, X.; Zhou, M.; Zhang, S.; Yao, H.; Zhao, W.; Xia, A.; Ade, H.; Hou, J. Manipulating Aggregation and Molecular Orientation in All-Polymer Photovoltaic Cells. Adv. Mater. 2015, 27, 6046-6054. [CrossRef] [PubMed]

17. Li, Y. Molecular Design of Photovoltaic Materials for Polymer Solar Cells: Toward Suitable Electronic Energy Levels and Broad Absorption. Acc. Chem. Res. 2012, 45, 723-733. [CrossRef] [PubMed]

18. Bin, H.; Gao, L.; Zhang, Z.; Yang, Y.; Zhan, Y.; Zhang, C.; Chen, S.; Xue, L.; Yang, C.; Xiao, M.; et al. 11.4\% Efficiency non-fullerene polymer solar cells with trialkylsilyl substituted 2D-conjugated polymer as donor. Nat. Commun. 2016, 7, 13651. [CrossRef] [PubMed]

19. Zhang, S.; Ye, L.; Hou, J. Breaking the 10\% Efficiency Barrier in Organic Photovoltaics: Morphology and Device Optimization of Well-Known PBDTTT Polymers. Adv. Energy Mater. 2016, 6, 1502529. [CrossRef]

20. Min, J.; Luponosov, Y.N.; Zhang, Z.G.; Ponomarenko, S.A.; Ameri, T.; Li, Y.; Brabec, C.J. Interface Design to Improve the Performance and Stability of Solution-Processed Small-Molecule Conventional Solar Cells. Adv. Energy Mater. 2014, 4, 1400816. [CrossRef]

21. Stubhan, T.; Litzov, I.; Li, N.; Salinas, M.; Steidl, M.; Sauer, G.; Forberich, K.; Matt, G.J.; Halik, M.; Brabec, C.J. Overcoming interface losses in organic solar cells by applying low temperature, solution processed aluminum-doped zinc oxide electron extraction layers. J. Mater. Chem. A 2013, 1, 6004-6009. [CrossRef]

22. Norrman, K.; Gevorgyan, S.A.; Krebs, F.C. Water-Induced Degradation of Polymer Solar Cells Studied by H218O Labeling. ACS Appl. Mater. Interfaces 2009, 1, 102-112. [CrossRef] [PubMed] 
23. Kawano, K.; Pacios, R.; Poplavskyy, D.; Nelson, J.; Bradley, D.D.C.; Durrant, J.R. Degradation of organic solar cells due to air exposure. Sol. Energy Mater. Sol. Cells 2006, 90, 3520. [CrossRef]

24. Sun, Y.; Seo, J.H.; Takacs, C.J.; Seifter, J.; Heeger, A.J. Inverted Polymer Solar Cells Integrated with a Low-Temperature-Annealed Sol-Gel-Derived ZnO Film as an Electron Transport Layer. Adv. Mater. 2011, 23, 1679-1683. [CrossRef] [PubMed]

25. Sun, Y.; Takacs, C.J.; Cowan, S.R.; Seo, J.H.; Gong, X.; Roy, A.; Heeger, A.J. Efficient, Air-Stable Bulk Heterojunction Polymer Solar Cells Using $\mathrm{MoO}_{x}$ as the Anode Interfacial Layer. Adv. Mater. 2011, 23, 2226-2230. [CrossRef] [PubMed]

26. Krebs, F.C. Polymer solar cell modules prepared using roll-to-roll methods: Knife-over-edge coating, slot-die coating and screen printing. Sol. Energy Mater. Sol. Cells 2009, 93, 465-475. [CrossRef]

27. He, Z.; Zhong, C.; Su, S.; Xu, M.; Wu, H.; Cao, Y. Enhanced power-conversion efficiency in polymer solar cells using an inverted device structure. Nat. Photon. 2012, 6, 591-595. [CrossRef]

28. Li, G.; Chu, C.-W.; Shrotriya, V.; Huang, J.; Yang, Y. Efficient inverted polymer solar cells. Appl. Phys. Lett. 2006, 88, 253503. [CrossRef]

29. Waldauf, C.; Morana, M.; Denk, P.; Schilinsky, P.; Coakley, K.; Choulis, S.A.; Brabec, C.J. Highly efficient inverted organic photovoltaics using solution based titanium oxide as electron selective contact. Appl. Phys. Lett. 2006, 89, 233517. [CrossRef]

30. Lin, Z.; Jiang, C.; Zhu, C.; Zhang, J. Development of Inverted Organic Solar Cells with $\mathrm{TiO}_{2}$ Interface Layer by Using Low-Temperature Atomic Layer Deposition. ACS Appl. Mater. Interfaces 2013, 5, 713-718. [CrossRef] [PubMed]

31. Liu, J.; Shao, S.; Meng, B.; Fang, G.; Xie, Z.; Wang, L.; Li, X. Enhancement of inverted polymer solar cells with solution-processed $\mathrm{ZnO}-\mathrm{TiO}_{X}$ composite as cathode buffer layer. Appl. Phys. Lett. 2012, 100, 213906. [CrossRef]

32. Cheun, H.; Fuentes-Hernandez, C.; Shim, J.; Fang, Y.; Cai, Y.; Li, H.; Sigdel, A.K.; Meyer, J.; Maibach, J.; Dindar, A.; et al. Oriented Growth of $\mathrm{Al}_{2} \mathrm{O}_{3}: \mathrm{ZnO}$ Nanolaminates for Use as Electron-Selective Electrodes in Inverted Polymer Solar Cells. Adv. Funct. Mater. 2012, 22, 1531-1538. [CrossRef]

33. Shao, S.; Zheng, K.; Pullerits, T.; Zhang, F. Enhanced Performance of Inverted Polymer Solar Cells by Using Poly(ethylene oxide)-Modified ZnO as an Electron Transport Layer. ACS Appl. Mater. Interfaces 2013, 5, 380-385. [CrossRef] [PubMed]

34. Lin, Z.; Chang, J.; Zhang, C.; Zhang, J.; Wu, J.; Hao, Y. Low temperature aqueous solution-processed Li doped ZnO buffer layers for high performance inverted organic solar cells. J. Mater. Chem. C 2016, 4, 6169-6175. [CrossRef]

35. Chang, J.; Lin, Z.; Zhu, C.; Chi, C.; Zhang, J.; Wu, J. Solution-Processed LiF-Doped ZnO Films for High Performance Low Temperature Field Effect Transistors and Inverted Solar Cells. ACS Appl. Mater. Interfaces 2013, 5, 6687-6693. [CrossRef] [PubMed]

36. Yin, Z.; Zheng, Q.; Chen, S.-C.; Cai, D.; Zhou, L.; Zhang, J. Bandgap Tunable $Z_{n_{1-x}} \mathrm{Mg}_{x} \mathrm{O}$ Thin Films as Highly Transparent Cathode Buffer Layers for High-Performance Inverted Polymer Solar Cells. Adv. Energy Mater. 2014, 4, 1301404. [CrossRef]

37. Pachoumi, C.; Li, Y.; Vaynzof, K.K.; Banger, H. Sirringhaus. Improved Performance and Stability of Inverted Organic Solar Cells with Sol-Gel Processed, Amorphous Mixed Metal Oxide Electron Extraction Layers Comprising Alkaline Earth Metals. Adv. Energy Mater. 2013, 3, 1428-1436. [CrossRef]

38. Liang, Z.; Zhang, Q.; Jiang, L.; Cao, G. ZnO cathode buffer layers for inverted polymer solar cells. Energy Environ. Sci. 2015, 8, 3442-3476. [CrossRef]

39. Zhang, C.; You, H.; Lin, Z.; Hao, Y. Inverted organic photovoltaic cells with solution-processed zinc oxide as electron collecting layer. Jpn. J. Appl. Phys. 2011, 5, 082302. [CrossRef]

40. Chen, D.; Zhang, C.; Wei, W.; Wang, Z.; Heng, T.; Tang, S.; Han, G.; Zhang, J.; Hao, Y. Stability of inverted organic solar cells with low-temperature $\mathrm{ZnO}$ buffer layer processed from aqueous solution. Phys. Status Solidi A 2015, 212, 2262-2270. [CrossRef]

41. Chen, D.; Zhang, C.; Heng, T.; Wei, W.; Wang, Z.; Han, G.; Feng, Q.; Hao, Y.; Zhang, J. Efficient inverted polymer solar cells using low-temperature zinc oxide interlayer processed from aqueous solution. Jpn. J. Appl. Phys. 2015, 54, 042301. [CrossRef] 
42. Wei, W.; Zhang, C.; Chen, D.; Wang, Z.; Zhu, C.; Zhang, J.; Lu, X.; Hao, Y. Efficient “Light-soaking"-free Inverted Organic Solar Cells with Aqueous Solution Processed Low-Temperature ZnO Electron Extraction Layers. ACS Appl. Mater. Interfaces 2013, 5, 13318-13324. [CrossRef] [PubMed]

43. You, H.; Zhang, J.; Zhang, C.; Lin, Z.; Chen, D.; Chang, J.; Zhang, J. Efficient flexible inverted small-bandgap organic solar cells with low-temperature zinc oxide interlayer. Jpn. J. Appl. Phys. 2016, 55, 122302. [CrossRef]

44. You, H.; Zhang, J.; Zhang, Z.; Zhang, C.; Lin, Z.; Chang, J.; Han, G.; Zhang, J.; Lu, G.; Hao, Y. Low Temperature Aqueous Solution-Processed $\mathrm{ZnO}$ and Polyethylenimine Ethoxylated Cathode Buffer Bilayer for High Performance Flexible Inverted Organic Solar Cells. Energies 2017, 10, 494. [CrossRef]

45. Lin, Y.; Thomas, S.R.; Faber, H.; Li, R.; McLachlan, M.A.; Patsalas, P.A.; Anthopoulos, T.D. Al-Doped ZnO Transistors Processed from Solution at $120^{\circ} \mathrm{C}$. Adv. Electron. Mater. 2016, 2, 1600070. [CrossRef]

46. Zhang, C.; Zhang, J.; Hao, Y.; Lin, Z.; Zhu, C. A simple and efficient solar cell parameter extraction method from a single current-voltage curve. J. Appl. Phys. 2011, 110. [CrossRef]

47. Chen, M.-H.; Kuo, Y.-C.; Lin, H.-H.; Chao, Y.-P.; Wong, M.-S. Highly stable inverted organic photovoltaics using aluminum-doped zinc oxide as electron transport layers. J. Power Sources 2015, 275, 274-278. [CrossRef]

(C) 2018 by the authors. Licensee MDPI, Basel, Switzerland. This article is an open access article distributed under the terms and conditions of the Creative Commons Attribution (CC BY) license (http://creativecommons.org/licenses/by/4.0/). 